\title{
Parametars for the evaluation of the quality of PVC containers for pharmaceutical preparations
}

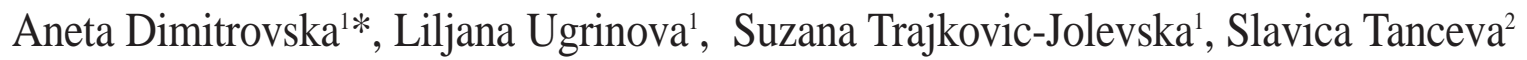 \\ ${ }^{1}$ Institute of Drug Quality Control, Faculty of Pharmacy, Sts. Cyril and Methodius University, \\ Vodnjanska 17, 1000 Skopje, Macedonia, ㄹHIS A.D., 1000 Skopje, Macedonia
}

Received April 2001; accepted March 2002

\begin{abstract}
An overview of the parameters for the evaluation of the quality of poly(vinyl chloride) (PVC) containers for pharmaceutical preparations is made. The requirements for the quality of PVC containers regulated by Ph. Eur., DIN and ISO standards differ in the prescribed parameters for physical, chemical and biological examination. Different ranges of tolerance for certain parameters also exist. The comparison of the parameters prescribed for these types of containers in Ph. Eur., DIN and ISO standards is made for a more detailed evaluation of PVC container quality.
\end{abstract}

Key words: poly(vinyl chloride) containers, pharmaceutical preparations, evaluation of the quality

\section{Introduction}

The primary containers used for packing of pharmaceutical preparations should provide a physically, chemically and microbiologically stable, therapeutically effective and non-toxic product within the date of expiry.

The material used for the production of containers for pharmaceutical preparations should comprise one or more polymers, including some additives (lubricants, stabilizators, plastificators, anti-oxidants, colors and pigments, anti-static agents, etc.)

The most widely used polymers include: polyethylene (low and high density), polypropylene, poly(vinyl chloride), poly(ethylene tereftalate) and ethyl-vinyl acetate copolymer (1). The polymer of choice used for the packaging of water solutions for intravenous infusion and packaging for blood and blood elements of human origin, is plastificated poly(vinyl chloride).

\footnotetext{
* e-mail:aneta.dimitrovska@baba.ff.ukim.edu tel: 126024 Fax: 123054
}

Physico-chemical methods and separative techniques are widely used for the evaluation of the quality of pharmaceutical containers (2). Among the spectroscopic methods, infrared spectroscopy is the method of choice for the identification of the components that comprise the contents of the containers in question; ultraviolet spectroscopy for the identification and the quantitative determination of extractive additives that contain conjugated double bonds and aromatic rings; and atomic absorption spectroscopy for the determination of trace metals. Among the separative techniques, thin-layer chromatography is most often used for identification; high-pressure liquid chromatography for the separation of the main polymer of the additives, their identification and determination, and gas chromatography for the determination of some monomers as impurities, for example vinyl chloride (2).

The aim of this study is to determine the quality of PVC containers for pharmaceutical preparations using selected parameters, grouped as physical, chemical and biological tests. An overview and comparison of the parameters prescribed for this type of containers in Ph. Eur., DIN and DIN ISO standards will be carried out for a more detailed assessment of the quality of PVC containers. 


\section{Experimental}

\section{Materials}

Poly(vinyl chloride) bags for aqueous solutions for intravenous infusion (500 ml), (sample 1) and sterile containers of plasticised poly(vinyl chloride) for human blood containing an anticoagulative solution (450 ml) (sample 2).

\section{Methods}

For the evaluation of the quality of the material in question, physical, chemical and biological studies were conducted according to the steps outlined in:

- Ph. Eur.

- DIN 53 363-15 - Infusion bags and bottles made of plastic (sample 1)

- DIN ISO 3826 - Plastics collapsible containers for humanblood and blood components (sample 2)

- Internal procedures for the determination of the content of a PVC polymer; plastificator and liquid stabilizators, fillers and solid stabilizators and vinyl chloride content.

Preparation of the test solution and blank for the chemical and biological tests was done according to the steps outlined in Ph. Eur. (by autoclavation at $110^{\circ} \mathrm{C}$ for 30 minutes with distilled water and sterile apirogen $0.9 \%$ solution of $\mathrm{NaCl}$ for chemical and biological test, respectively).

\section{Results and discussion}

\section{Physical tests}

The physical tests of the PVC containers include examination of appearance, dimensions, thickness of the walls, resistance to temperature, pressure and sealing, resistance to centrifugation and leakage, stretching, with the goal of evaluating the physical characteristics of the packaging.

The thickness of the wall of the plastic containers should provide the packaging to be non-permeable to gases, moisture and microorganisms, thus ensuring the quality of the pharmaceutical preparation until the expiry date. Permeability for gases, moisture and microorganisms decreases with increased thickness of the wall of the containers. The thinnest plastic packaging should be $0.1 \mathrm{~mm}$. Double this thickness $(0.2 \mathrm{~mm})$ decreases the permeability for gasses by $70 \%$. The manufacturers of different plastic containers for pharmaceutical preparations suggest that the thinnest wall should be $0.3 \mathrm{~mm}$, which would ensure the quality of the plastic containers regarding permeability. However, the walls of the plastic containers should not be abnormally thick because the plastic packaging should posses a certain flexibility that allows easy and complete filling and emptying, ensuring a correct way of administering the medication.

Table 1. Physical tests on PVC containers for aqueous solutions for intravenous infusion

\begin{tabular}{|c|c|c|c|}
\hline \multirow[t]{2}{*}{ Parameters } & \multirow{2}{*}{$\begin{array}{l}\text { Results } \\
\text { Sample } 1\end{array}$} & \multicolumn{2}{|c|}{ Standards and Limits } \\
\hline & & Ph. Eur. & DIN 58363 - 15 \\
\hline $\begin{array}{l}\text { Resistance to temperature, } \\
\text { pressure and sealing }\end{array}$ & complies $^{\text {DIN }}$ & $/ *$ & $\begin{array}{l}-25^{0} \mathrm{C} \text { to } 50{ }^{0} \mathrm{C} \text { for } 24 \text { hours internal pressure: } \\
20 \mathrm{kPa} \text { for } 10 \mathrm{~min} \text {. }\end{array}$ \\
\hline Resistance to fall & complies $^{\text {DIN }}$ & $/ *$ & Fall from $2 \mathrm{~m}$ on hard base \\
\hline Vapor permeability & complies $^{\text {DIN }}$ & $/ *$ & $\begin{array}{l}\mathrm{T}=20 \pm 5{ }^{0} \mathrm{CRH} \leq 60 \% \text { for } 21 \text { days } \\
\text { Loss in mass is not greater than } 5 \% \text { for the } \\
\text { shelf life of a plastic container }\end{array}$ \\
\hline Transparency & complies $^{\text {Ph Eur }}$ & $\begin{array}{c}\text { Primary opalescent suspension } \\
\text { diluted } 1 \text { in } 400\end{array}$ & Primary opalescent suspension $(1: 100)$ \\
\hline Attaching to plastic bag & complies $^{\text {DIN }}$ & $/ *$ & $\begin{array}{l}\text { Part intended for attachment required to stand } \\
\text { force from } 25 \mathrm{~N} \text { for } 60 \mathrm{~min} \text {. }\end{array}$ \\
\hline Permanence of labeling & complies $^{\text {DIN }}$ & $/ *$ & $\begin{array}{l}\text { The printing on the label remains legible and the } \\
\text { label shall not separate from the container after } \\
\text { removal from water if plastic container is } \\
\text { submerged in water at a temperature } 20 \pm 1{ }^{0} \mathrm{C} \text { for } \\
24 \text { hours }\end{array}$ \\
\hline Appearance & complies & Internal & ecification \\
\hline Dimensions & complies & Internal & ecification \\
\hline Thickness of wall (mm) & 0.35 & Internal & ecification \\
\hline
\end{tabular}

$\mathrm{n}=6$; $\quad$ * parameter is not prescribed for examination 
Table 2. Physical tests on sterile containers of plasticised PVC for human blood containing an anticoagulant solution

\begin{tabular}{|c|c|c|c|}
\hline \multirow[t]{2}{*}{ Parameters } & \multirow{2}{*}{$\begin{array}{c}\text { Results } \\
\text { Sample } 2\end{array}$} & \multicolumn{2}{|c|}{ Standards and Limits } \\
\hline & & Ph. Eur. & DIN ISO 3826 \\
\hline $\begin{array}{l}\text { Resistance to } \\
\text { centrifugation }\end{array}$ & complies $^{\text {Ph Eur }}$ & $\begin{array}{l}5000 \mathrm{~g} \text { for } 10 \mathrm{~min} . \\
\text { no leakage perceptible and } \\
\text { no permanent distortion occur }\end{array}$ & $\begin{array}{l}5000 \mathrm{~g} \text { for } 30 \mathrm{~min} . \\
\mathrm{T}=4{ }^{0} \mathrm{C} \text { and } \mathrm{T}=37{ }^{0} \mathrm{C} \\
\text { no leakage perceptible and } \\
\text { no permanent distortion occur }\end{array}$ \\
\hline Resistance to stretch (\%) & $3.82^{\mathrm{Ph} \text { Eur }}$ & $20 \mathrm{~N}$ & $20 \mathrm{~N}$ \\
\hline Leakage & complies $^{\text {Ph Eur }}$ & Internal pressure: $100 \mathrm{kPa}$ for $10 \mathrm{~min}$. & $\begin{array}{l}\text { Internal pressure: } \\
67 \mathrm{kPa} \text { for } 10 \mathrm{~min} .\end{array}$ \\
\hline Vapor permeability & complies $^{\text {Ph Eur }}$ & $\begin{array}{l}\mathrm{T}=5 \pm 1{ }^{0} \mathrm{C} \\
\mathrm{RH}=50 \pm 5 \% \text { for } 6 \text { weeks } \\
\text { Loss in mass: } \max 2 \%\end{array}$ & $\begin{array}{l}\mathrm{T}=5 \pm 1{ }^{0} \mathrm{C} \\
\mathrm{RH}=50 \pm 5 \% \text { for } 21 \text { days } \\
\text { Loss in mass: } \max 1 \%\end{array}$ \\
\hline Emptying under pressure & complies $^{\text {Ph Eur }}$ & $\begin{array}{l}\text { Internal pressure: } 40 \mathrm{kPa} \\
\text { The container empties in less than } 2 \mathrm{~min} \text {. }\end{array}$ & $\begin{array}{l}\text { Internal pressure: } 40 \mathrm{kPa} \\
\text { The container empties in less than } 2 \mathrm{~min} \text {. }\end{array}$ \\
\hline Speed of filling & complies $^{\text {Ph Eur }}$ & $\begin{array}{l}\text { Internal pressure: } 9.3 \mathrm{kPa} \\
\text { The volume of liquid which flows into } \\
\text { the container in } 8 \text { min. is not less than the } \\
\text { nominal capacity of the container }\end{array}$ & $\begin{array}{l}\text { Internal pressure: } 9.3 \mathrm{kPa} \\
\text { The volume of liquid which flows into } \\
\text { the container in } 8 \text { min. is not less than the } \\
\text { nominal capacity of the container }\end{array}$ \\
\hline $\begin{array}{l}\text { Resistance to } \\
\text { temperature variations }\end{array}$ & complies $^{\text {Ph Eur }}$ & $\begin{array}{l}\mathrm{T}=-80{ }^{0} \mathrm{C} \text { for } 24 \text { hours } \\
\mathrm{T}=50{ }^{\circ} \mathrm{C} \text { for } 20 \mathrm{~min} .\end{array}$ & $\begin{array}{l}\mathrm{T}=-80{ }^{0} \mathrm{C} \text { for } 24 \text { hours } \\
\mathrm{T}=50{ }^{0} \mathrm{C} \text { for } 12 \text { hours }\end{array}$ \\
\hline Transparency & complies $^{\text {Ph Eur }}$ & Primary opalescent suspension $(1: 16)$ & Primary opalescent suspension $(1: 16)$ \\
\hline Appearance & complies & Internal & cification \\
\hline Dimensions & complies & Internal & cification \\
\hline Thickness of wall (mm) & 0.37 & Internal & cification \\
\hline
\end{tabular}

The thickness of the wall of the tested PVC bags for water solutions for intravenous infusion and blood and blood products varies within the range of $0.33-0.38 \mathrm{~mm}$, declared by the manufacturer. The tested PVC bags also meet the other physical requirements important for the quality of the containers (Table 1 and 2).

Parameters such as resistance to centrifugation, leakage, empting under pressure, speed of filling are specific for assessment of the quality of the PVC containers for human blood. These PVC bags also meet the requirements for resistance to stretching that is important for the containers' quality. Among the tested containers, there were no examples of tearing or prolonged deformation of the material during the application of a force of $20 \mathrm{~N}$, due to the elastic properties of the plastic containers. A larger percentage of stretching, without tearing or prolonged deformation of the material, implies better elastic properties.

\section{Chemical tests}

The identification of the main polymer, poly(vinyl chloride) and the corresponding plastificator for PVC containers, di(2-ethylhexyl) phthalate (DEHP), was done using IR spectroscopy, in comparison with the referent IR spectra (3) and the IR spectra of the standard substances.

After the separation of the plastificator DEHP and PVC (extraction with diethyl ether in an apparatus by Soxlet) in the appropriate PVC packaging, they were re-identified by the IR method, which confirms their presence. A thin layer of the sample in tetrahydrofuran was applied to a $\mathrm{NaCl}$ plate and the spectra were recorded in the range from 4000 to $600 \mathrm{~cm}^{-1}$. The resulting IR spectra are shown in Fig. 1.

The results of the chemical tests on investigated PVC bags are given in Table 3 and 4.

The requirements for the quality of the PVC packaging are regulated by Ph. Eur., DIN and ISO standards. In order to make a complete evaluation of the investigated PBC bags' quality, all the parameters prescribed in these standards were included.

The requirements for the physical parameters of plastic bags for water solutions for intravenous infusion, except for its transparency, are not specified by Ph. Eur., unlike the DIN standard, which sets out exact regulations; the confirmation of 
(a)

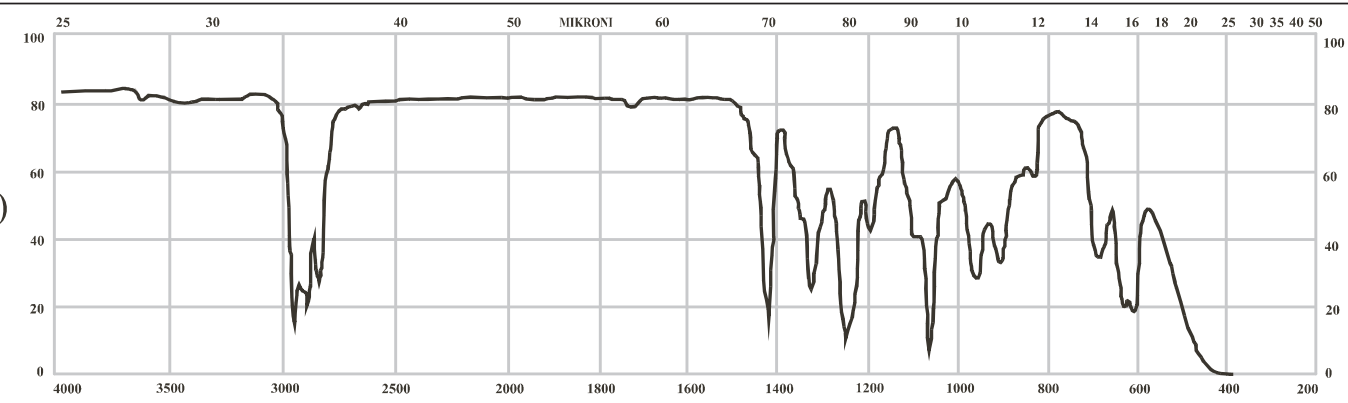

(b)

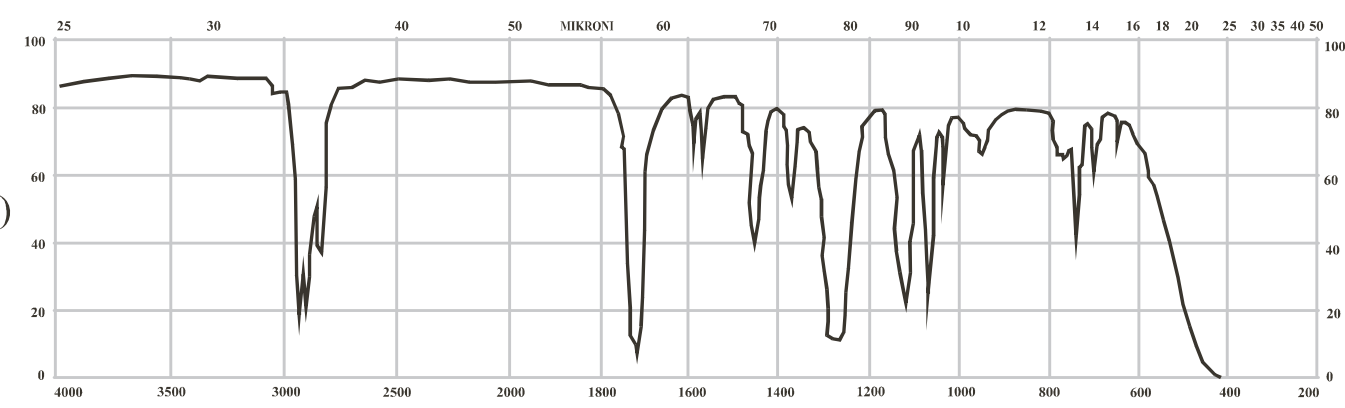

(c)

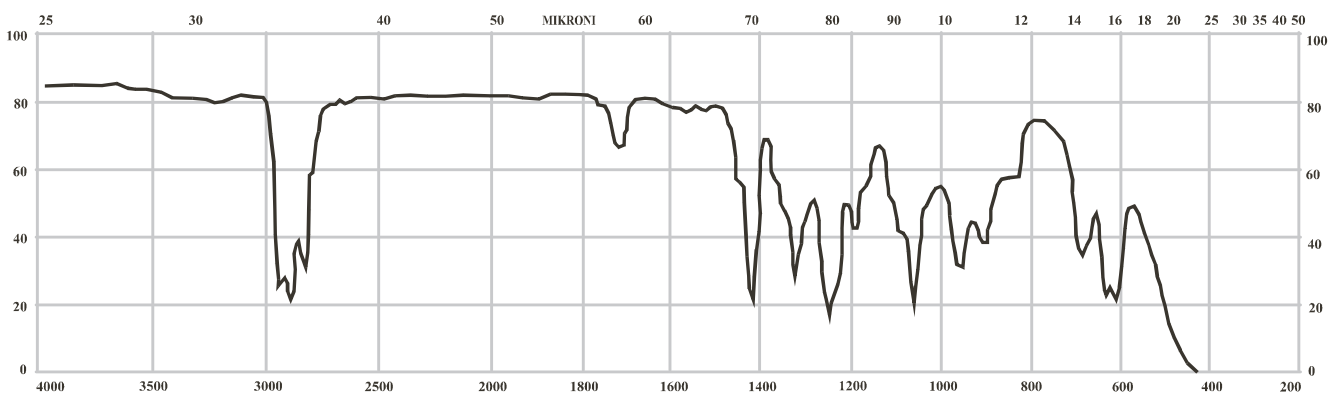

(d)

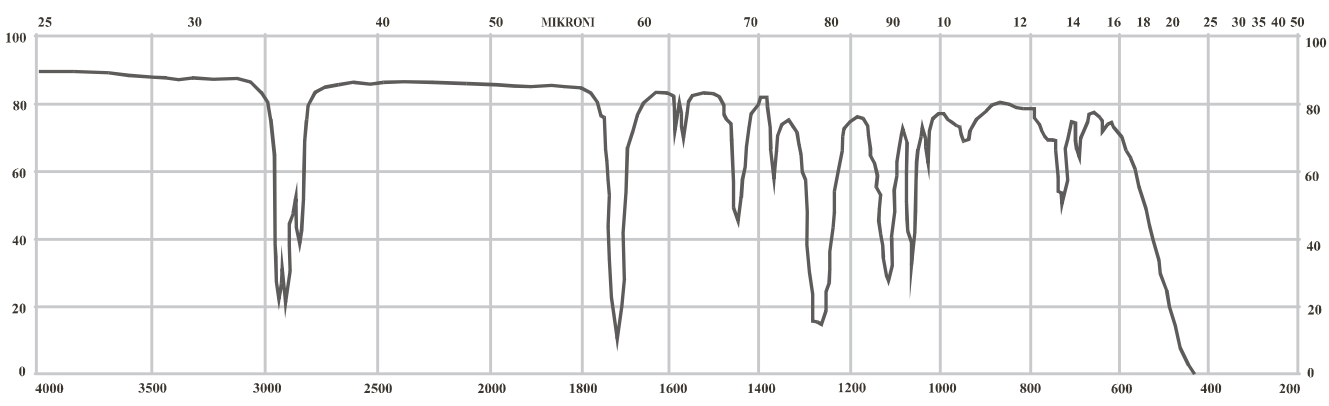

Fig. 1. IR spectra of PVC (a) and DEHP (b), standard substances; PVC (c) and DEHP (d) after their separation from sample 1

the presence of impurities such as $\mathrm{SO}_{4}^{2-}, \mathrm{NH}_{4}^{+}$, and $\mathrm{Cl}$; as part of the chemical tests prescribed for $\mathrm{PVC}$ is not prescribed in $\mathrm{Ph}$. Eur. for PVC bags for water solutions for intravenous infusion, whereas such regulations are upheld by the DIN standard. Furthermore, Ph. Eur. does not require tests for the presence of heavy metals in all types of plastic packaging, whereas DIN and DIN ISO standards do require the test for heavy metals represented as $\mathrm{Pb}^{2+}$ or their individual determination, for example: $\mathrm{Ba}, \mathrm{Cr}, \mathrm{Cu}, \mathrm{Pb}, \mathrm{Sn}, \mathrm{Cd}$, and $\mathrm{Al}$ for plastic packaging for water solutions for intravenous infusions, and $\mathrm{Ba}, \mathrm{Pb}$, Sn and $\mathrm{Cd}$ for plastic packaging for blood and blood products. In contrast to $\mathrm{Ph}$. Eur., the DIN standard also requires testing for mechanical impurities in plastic bags for water solutions for intravenous infusions with the exact number and size of the particles.

In addition, the allowed presence of $\mathrm{Cl}^{-}$as an impurity in PVC packaging for blood and blood products is $0.4 \mathrm{ppm}$ and 4 ppm according to Ph. Eur. and DIN ISO standards respectively. 
Table 3. Results of chemical tests on PVC containers for aqueous solutions for intravenous infusion

\begin{tabular}{|c|c|c|c|}
\hline \multirow[t]{2}{*}{ Parameters } & \multirow{2}{*}{$\begin{array}{c}\text { Results } \\
\text { Sample } 1\end{array}$} & \multicolumn{2}{|c|}{ Standards and Limits } \\
\hline & & Ph. Eur. & DIN $58363-15$ \\
\hline $\begin{array}{l}\text { Appearance of solution } \\
\text { clarity/color }\end{array}$ & complies $^{\text {Ph Eur }}$ & Clear and colorless solution & $\begin{array}{l}\text { Clear solution, not more opalescent } \\
\text { than reference suspension }\end{array}$ \\
\hline Acidity or alkalinity & complies $^{\text {Ph Eur }}$ & $\begin{array}{l}\max .0 .4 \mathrm{ml} 0.01 \mathrm{~mol} / \mathrm{L} \mathrm{NaOH} \text { or } \\
\text { max. } 0.8 \mathrm{ml} 0.01 \mathrm{~mol} / \mathrm{L} \mathrm{HCl} / 4 \% \\
\text { of the nominal capacity of the } \\
\text { container }\end{array}$ & $\begin{array}{l}\max .0 .8 \mathrm{ml} 0.01 \mathrm{~mol} / \mathrm{L} \mathrm{NaOH} \text { or } \\
\max .0 .8 \mathrm{ml} 0.01 \mathrm{~mol} / \mathrm{L} \mathrm{HCl} / 20 \mathrm{ml}\end{array}$ \\
\hline $\mathrm{pH}(4.0-4.5)$ & $5.56^{\text {DIN } 13098}$ & $/ *$ & $/ *$ \\
\hline Mechanical particles & complies $^{\text {DIN } 58363-15}$ & $/ *$ & $\begin{array}{l}\text { Particles } \geq 2 \mu \mathrm{m}: \\
\text { max. } 200 / \mathrm{ml} \\
\text { Particles } \geq 5 \mu \mathrm{m}: \\
\text { max. } 20 / \mathrm{ml}\end{array}$ \\
\hline $\begin{array}{l}\text { Absorbance } \\
(230-360 \mathrm{~nm})\end{array}$ & $\begin{array}{l}0.020^{\text {Ph Eur }} \\
(250 \mathrm{~nm})\end{array}$ & $\max .0 .200$ & $\max .0 .250$ \\
\hline $\begin{array}{l}\text { Oxidisable substances } \\
(\mathrm{mlA}-\mathrm{mlSl}) 0.002 \mathrm{~mol} / \mathrm{L} \\
\mathrm{KMnO}_{4}\end{array}$ & $0.65 \mathrm{ml}^{\mathrm{Ph} \text { Eur }}$ & $\max .1 .5 \mathrm{ml}$ & $\max .3 .0 \mathrm{ml}$ \\
\hline $\mathrm{SO}_{4}^{2-}$ & complies DIN 58 363-15 & /* & 10 ppm \\
\hline $\mathrm{NH}_{4}^{+}$ & complies $^{\text {DIN } 58 \text { 363-15 }}$ & $/ *$ & $0.8 \mathrm{ppm}$ \\
\hline $\mathrm{Cl}^{-}$ & complies $^{\text {DIN } 58 \text { 363-15 }}$ & $/ *$ & $4 \mathrm{ppm}$ \\
\hline $\begin{array}{l}\text { Residue on evaporation } \\
(\mathrm{mg} / 100 \mathrm{ml})\end{array}$ & $2.57^{\text {DIN 58363-15 }}$ & $/ *$ & 5.0 \\
\hline Heavy metals (ppm) & $\begin{array}{l}\mathrm{Pb}=0.00 \\
\mathrm{Cd}=0.00 \\
\mathrm{Sn}=0.00 \\
(\mathrm{DIN} 58363-15)\end{array}$ & $/ *$ & $\begin{array}{l}\text { 1. } \mathrm{Pb}^{2+}: 1.6 \mathrm{ppm} \\
\text { 2. AAS } \\
\mathrm{Ba}, \mathrm{Cr}, \mathrm{Cu}, \mathrm{Pb}: 1 \mathrm{ppm} \\
\text { Sn, Cd: } 0.1 \mathrm{ppm} \\
\text { Al: } 0.01 \mathrm{ppm}\end{array}$ \\
\hline
\end{tabular}

$\mathrm{n}=6$; /* parameter is not prescribed for examination

The total content of the plastificator DEHP and the liquid stabilizators is determined by gravimetric means, after a 16 -hour extraction period with diethyl ether in an apparatus by Soxlet. The content of the PVC polymer is determined gravimetrically after dissolving the residue, obtained from extraction, in cyclohexanon and its precipitation with methanol. The content of the fillers and solid stabilizators are represented by the undissolved part in cyclohexanon, as dry residue.

According to the specifications of Ph. Eur., the content of the PVC polymer in PVC primary containers intended for water solution for intravenous infusions and blood and blood products should be at least $55 \%$. The determined content of the PVC polymer in the samples is above the required minimum, and the necessary elasticity of the PVC bags is obtained by the addition of a plastificator in content of max. $40 \%$, as specified in Ph. Eur.

The content of extractive di(2-ethylhexyl)phthalate (DEPH), used as a plastificator, is also tested in order to determine the PVC containers' quality. Determination of the content of DEPH extracted from the solvent is accomplished through a calibration graph constructed by the absorbances of the solutions of 
Table 4. Results of chemical tests on sterile containers of plasticised PVC for human blood containing an anticoagulant solution

\begin{tabular}{|c|c|c|c|}
\hline \multirow[t]{2}{*}{ Parameters } & \multirow{2}{*}{$\begin{array}{c}\text { Results } \\
\text { Sample } 2\end{array}$} & \multicolumn{2}{|c|}{ Standards and Limits } \\
\hline & & Ph. Eur. & DIN ISO 3826 \\
\hline Appearance of solution & complies ${ }^{\text {DIN ISO }}$ & $/ *$ & $\begin{array}{l}\text { Clear solution, not more opalescent } \\
\text { than reference suspension II }\end{array}$ \\
\hline Volume of anticoagulant solution & complies $^{\text {Ph Eur }}$ & $\begin{array}{l} \pm 10 \% \text { from the stated volume } \\
\text { of anticoagulant solution }\end{array}$ & /* \\
\hline $\begin{array}{l}\text { Spectrophotometric examination } \\
\text { of anticoagulant sol. } \\
(250-350 \mathrm{~nm})\end{array}$ & $\begin{array}{l}0.030^{\mathrm{Ph} . \text { Eur }} \\
(280 \mathrm{~nm})\end{array}$ & $\begin{array}{l}\text { The absorbance at the maximum } \\
\text { at } 280 \mathrm{~nm} \text { is not greater than } 0.5\end{array}$ & /* \\
\hline Acidity or alkalinity & complies $^{\text {Ph Eur }}$ & $\begin{array}{l}\max .0 .4 \mathrm{ml} 0.01 \mathrm{~mol} / \mathrm{L} \mathrm{NaOH} \text { or } \\
\max .0 .8 \mathrm{ml} 0.01 \mathrm{~mol} / \mathrm{L} \mathrm{HCl} / 4 \% \\
\text { of the nominal capacity }\end{array}$ & $\begin{array}{l}\max .0 .4 \mathrm{ml} 0.01 \mathrm{~mol} / \mathrm{L} \mathrm{NaOH} \text { or } \\
\max .0 .8 \mathrm{ml} 0.01 \mathrm{~mol} / \mathrm{L} \mathrm{HCl} / 10 \mathrm{ml} \mathrm{sol} \text {. }\end{array}$ \\
\hline $\begin{array}{l}\text { Absorbance } \\
230-360 \mathrm{~nm}\end{array}$ & $\begin{array}{c}\text { no } \\
\text { absorbance }^{\text {Ph Eur }}\end{array}$ & $\begin{array}{l}\max .0 .300 \\
(230-250 \mathrm{~nm}) \\
\max .0 .100 \\
(251-360 \mathrm{~nm})\end{array}$ & max. 0.200 \\
\hline $\begin{array}{l}\text { Oxidisable substances } \\
\left(\mathrm{mlA} \text { - mlSl) } 0.002 \mathrm{~mol} / \mathrm{L} \mathrm{KMnO}_{4}\right.\end{array}$ & $0.45 \mathrm{ml}^{\mathrm{Ph} \text { Eur }}$ & $\begin{array}{l}\max .2 .0 \mathrm{ml} / 8 \% \text { of the nominal } \\
\text { capacity of the container }\end{array}$ & max. $2.0 \mathrm{ml} / 20 \mathrm{ml} \mathrm{sol}$. \\
\hline $\mathrm{NH}_{4}^{+}(\mathrm{ppm})$ & complies $^{\text {Ph Eutr }}$ & $2 \mathrm{ppm}$ & $2 \mathrm{ppm}$ \\
\hline $\mathrm{Cl}^{-}(\mathrm{ppm})$ & complies $^{\text {Ph Eutr }}$ & $0.4 \mathrm{ppm}$ & $4 \mathrm{ppm}$ \\
\hline $\begin{array}{l}\text { Extractable di(2-ethylhexyl)- } \\
\text { phthalate (DEHP) mg/100ml }\end{array}$ & $\begin{array}{l}\text { complies }^{\text {Ph. Eur }} \\
\quad \text { (Table 4) }\end{array}$ & $\begin{array}{l}10.0 \mathrm{mg} / 100 \mathrm{ml} \\
\text { (volume: } 300-500 \mathrm{ml} \text { ) } \\
13.0 \mathrm{mg} / 100 \mathrm{ml} \\
\text { (volume: } 150-300 \mathrm{ml} \text { ) } \\
14.0 \mathrm{mg} / 100 \mathrm{ml} \\
\text { (volume to } 150 \mathrm{ml} \text { ) }\end{array}$ & $10.0 \mathrm{mg} / 100 \mathrm{ml}$ \\
\hline Vinyl chloride & complies* & $1 \mathrm{ppm}$ & $1 \mathrm{ppm}$ \\
\hline PVC & $\begin{array}{l}\text { complies } \\
\text { (Table 3)* }\end{array}$ & $\min .55 \%$ & /* \\
\hline Plasticizers and liquid stabilizers & $\begin{array}{l}\text { complies } \\
\text { (Table 3)* }\end{array}$ & $\max .40 \%$ & $/ *$ \\
\hline $\begin{array}{l}\text { Residue on evaporation } \\
\text { (mg/100 mg) }\end{array}$ & $0.2^{\mathrm{Ph} \mathrm{Eur}}$ & $\max .3 .0 \mathrm{mg} / 100 \mathrm{ml}$ & $\max .3 .0 \mathrm{mg} / 100 \mathrm{ml}$ \\
\hline Heavy metals (ppm) & $\begin{array}{c}\mathrm{Pb}=0.00 \\
\mathrm{Cd}=0.00 \\
\mathrm{Sn}=0.00 \\
(\text { DIN ISO 3826) }\end{array}$ & $/ *$ & $\begin{array}{l}\text { AAS } \\
\text { Ba, Pb: } 1 \text { ppm } \\
\text { Sn, Cd: } 0.6 \text { ppm }\end{array}$ \\
\hline Ash (mg/g) & $0.1^{\text {DIN ISO } 3826}$ & $/ *$ & $1 \mathrm{mg} / \mathrm{g}$ \\
\hline
\end{tabular}

$\mathrm{n}=6 *$ - internal procedure;

* - parameter is not prescribed for examination

Table 5. Results of determination of PVC polymer and additives in PCV bags

\begin{tabular}{cccc}
\hline \hline Sample & PVC polymer (\%) & $\begin{array}{c}\text { Plastificator* } \\
\text { and liquid stabilizators (\%) }\end{array}$ & Fillers and solid stabilizators (\%) \\
\hline 1 & 71.05 & 28.95 & traces \\
2 & 63.66 & 36.44 & traces \\
\hline
\end{tabular}

*plastificator - di(2-ethylhexyl)phthalate (DEHP) 
DEHP, standard substance in the concentration range of 2 to 20 $\mathrm{mg} / 100 \mathrm{ml}$, at $\lambda=272 \mathrm{~nm}$. The regression line estimated by linear least-squares regression analysis is represented by the equation: $y=0.0271+0.0231 x$, with a correlation coefficient of 0.9994 . The content of vinyl chloride in the PVC packaging is determined by the method of gas chromatography (head space), FID detector and S/S column, 1/4, 6 m (15\% Diethylhexylsebacate /Chromosorb W DMCS, 80/100 mesh). The chromatogram of vinyl chloride, standard substance, and the chromatograms of vinyl chloride (VC) in PVC bags are given in Fig. 2.

The retention time for vinyl chloride, standard substance is approximately 4 minutes. The absence of a peak which corresponds to the retention time of vinyl chloride, standard substance, is noticeable in the chromatograms obtained from samples 1 and 2, implying total polymerization of the vinyl chloride - monomer in the process of production of the tested PVC containers. The concentration of the prepared standard solution of vinyl chloride of $1 \mathrm{ppm}$, at the same time represents the maximum allowed presence of VC in the PVC packaging, taking into consideration its toxicity and the possibility of its migration into the solution.

\section{Biological tests}

The most widely used tests for the biological study of this type of containers are: the pyrogen test, abnormal toxicity, the test for haemolysis and sterility (Ph. Eur.) and permeability of microorganisms (DIN).

The pyrogen test (4) is used to determine the presence of pyrogen substances of non-microbiological origin, most often originating from the packaging material.

The plastic masses are inert and do not show a toxic effect if the polymerization of the polymer is complete. If the final product is not well purified it could contain a substance or an additive which is not chemically bonded to the polymer. The monomers, plastificators, stabilizators, catalysts, fillers and other additives, which are molecules with a small molecular weight, can easily migrate into the solution and display a toxic
Table 6. Content of extractive DEPH, obtained by calibration graph

\begin{tabular}{lcc}
\hline \multicolumn{1}{c}{ Sample } & $\begin{array}{c}\text { Absorbance, } \\
\lambda=272 \mathrm{~nm}\end{array}$ & $\begin{array}{c}\text { Concentration }(\mathrm{mg} / 100 \mathrm{ml}) \\
(\max .10 \mathrm{mg} / 100 \mathrm{ml})\end{array}$ \\
\hline $\begin{array}{l}\text { 1. (bag with } \\
\text { capacity of } 500 \mathrm{ml})\end{array}$ & 0.1599 & 5.76 \\
$\begin{array}{l}\text { 2. (primary bag with } \\
\text { capacity of } 400 \mathrm{ml})\end{array}$ & 0.1506 & 5.36 \\
\hline
\end{tabular}

effect. Toxicity could also be a result of the migration of the glue and the ink used in the printing of the label into the solution. Beside the monomer and the additives, the presence of tin as a form of impurity could also lead to a hemolysis of the erythrocytes (5). Due to these, for the evaluation of plastic packaging quality, the test for abnormal toxicity and the test for hemolysis are also conducted.

A sterility test is prescribed only for sterile bags of plasticised poly(vinyl chloride) for human blood containing an anticoagulant solution (sample 2), following the membrane filtration procedure outlined in Ph. Eur.

The plastic packaging should not be permeable to microorganisms, as a secondary contamination of the product. The permeation of microorganisms is controlled by the appropriate thickness of the walls of the plastic packaging. A thickness of the plastic wall of $0.04 \mathrm{~mm}$, prevents the permeation of microorganisms into the solution. As the walls at the joining points could be thinner, the thickness of the walls of the plastic packaging should be at least $0.1 \mathrm{~mm}$.

A cultivating medium where the samples (PVC bags) were kept during the examination was innoculated with Bacillus subtilis varieties Niger NCTC 10073. The cultivating medium in the tested PVC bags stayed clear after the proposed time of incubation, which indicates the impermeability of the plastic packaging to the tested microorganism.

The tested primary containers intended for pharmaceutical preparations is apyrogen, nontoxic, sterile, and does not cause haemolysis to the erythrocytes and it is impermeable to microorganisms.

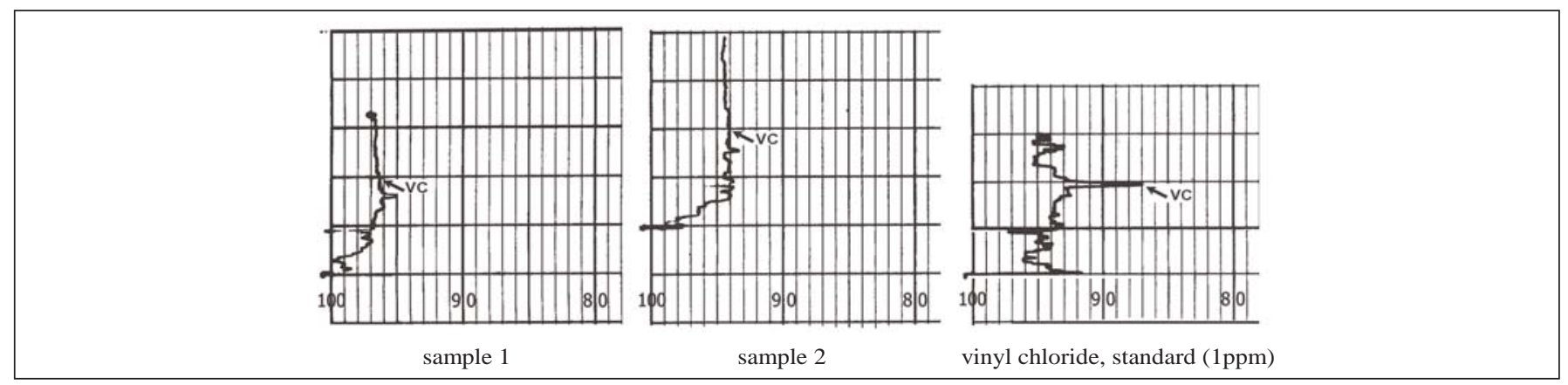

Fig 2. Chromatograms of determination of vinyl chloride in tested PVC containers and vinyl chloride, standard substance (1 ppm) in N,N dimethylacetamid 
Table 7. Results of biological tests on PVC bags

\begin{tabular}{|c|c|c|c|c|c|c|c|c|c|c|}
\hline \multirow{2}{*}{ 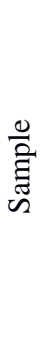 } & \multirow{2}{*}{ 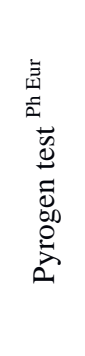 } & \multirow{2}{*}{ 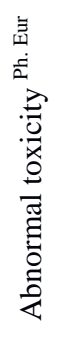 } & \multirow{2}{*}{ 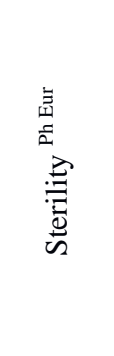 } & \multirow{2}{*}{ 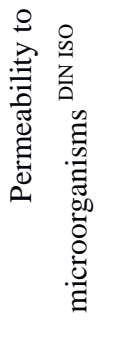 } & \multicolumn{6}{|c|}{$\begin{array}{l}\text { Haemolytic value (\%) } \\
\text { (max } 10 \%)\end{array}$} \\
\hline & & & & & $\begin{array}{c}\text { I } \\
\text { cell }\end{array}$ & $\begin{array}{l}\text { control } \\
\text { cell I }\end{array}$ & $\Delta \%$ & $\begin{array}{c}\text { II } \\
\text { cell }\end{array}$ & & $\%$ \\
\hline 1 & $\frac{\stackrel{\Xi}{\Xi}}{\stackrel{\Xi}{0}}$ & $\frac{\mathscr{\mathscr { Z }}}{\bar{\Xi}}$ & /* & 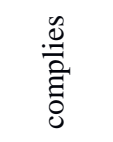 & 8.12 & 17.36 & 9.24 & 51.42 & & 9.39 \\
\hline 2 & 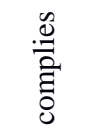 & 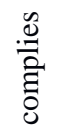 & 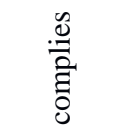 & 1* & 8.87 & 17.36 & 8.49 & 50.97 & & 9.84 \\
\hline & & & $\begin{array}{l}\stackrel{\vec{\Xi}}{\vec{\Phi}} \\
\stackrel{\tilde{\omega}}{n}\end{array}$ & & 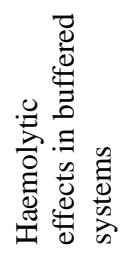 & 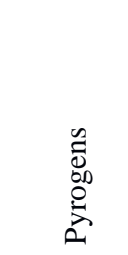 & 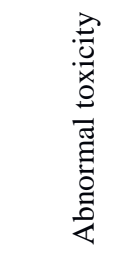 & & 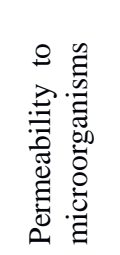 & 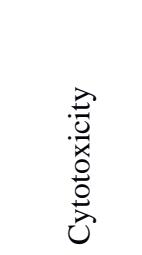 \\
\hline 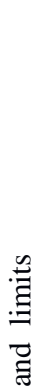 & $\begin{array}{l}\dot{\overrightarrow{\mid}} \\
\text { 亲 } \\
\dot{\vec{\Phi}}\end{array}$ & & 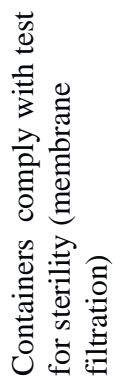 & & 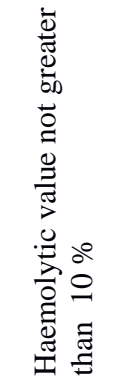 & 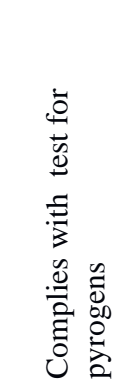 & 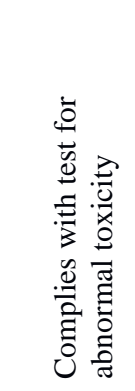 & & * & $\stackrel{*}{*}$ \\
\hline 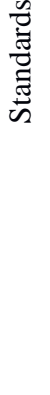 & 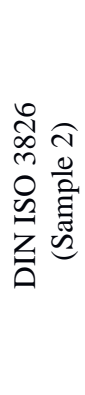 & & 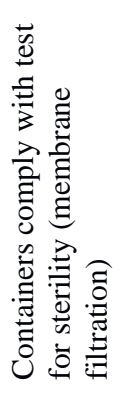 & & 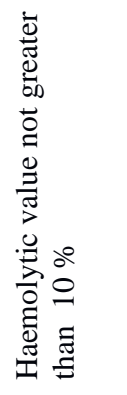 & 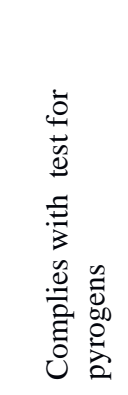 & 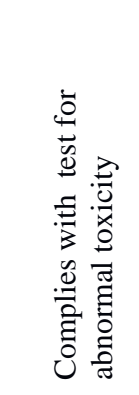 & & * & 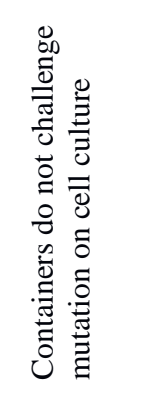 \\
\hline & 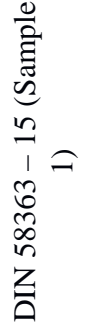 & & $\stackrel{*}{*}$ & & 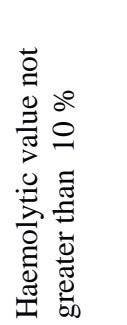 & 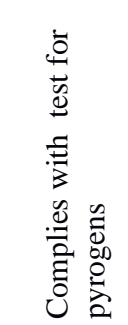 & 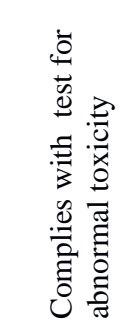 & & 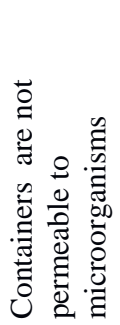 & 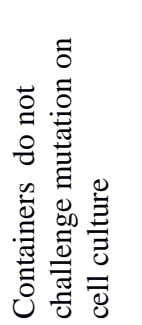 \\
\hline
\end{tabular}




\section{Conclusion}

The requirements for PVC container quality are regulated by Ph. Eur., DIN and DIN ISO standards. The specifications should encompass the parameters prescribed in Ph. Eur, DIN and DIN ISO standards for a more detailed evaluation of PVC container quality, and synchronize the allowed ranges of tolerance for certain parameters, as well.

\section{References}

1. European Pharmacopoeia, $3^{\text {rd }}$ Edition, Council of Europe, Strasbourg, 1997

2. A. Kenneth, L. Herbert and L. Leon, Pharmaceutical Dosage Form: Parenteral Medications, Part 10: Use of Plastics for parenteral packaging, $2^{\text {nd }}$ edition, Marcel Dekker, Inc., New York, 1992, pp 393- 433.

3. Hummel/Scholl, Infrared Analysis of Polymers, Resins and Additives An Atlas, Wiley-interscience, A Division of John Wiley \& Sons, Inc., New York, London, Toronto, 1969.

4. K. Richter, W. D. Grahlow and R. Wigert, Acta Biol. med. Ger., 39: 2-3, 277-280 (1980).

5. Remington: The Science and Practice of Pharmacy, Chapter 85: Plastic Packaging materials, 19 ${ }^{\text {th }}$ edition, MackPublishing company, Easton, Pennsylvania, 1995, pp 1487 - 1493.Вовед

\title{
Резиме
}

\section{Параметри за процена на квалитетот на PVC амбалажа наменета за фармацевтски препарати}

\author{
Анета Димитровска ${ }^{1}$, Лилјана Угринова ${ }^{1}$, Сузана Трајковиќ-Јолевска ${ }^{1}$, Славица Танчева ${ }^{2}$

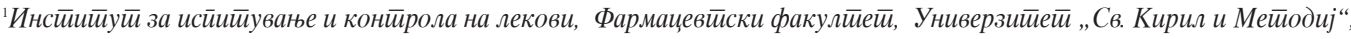 \\ Водњанска 17, 1000 Скойје, Македонија, ㄹХИС А.Д., 1000 Скойје, Македонија
}

Клучни зборови: поли(винил хлорид) амбалажа, фармацевтски препарати, процена на квалитет

Направен е преглед на параметрите за процена на квалитетот на поли(винил хлорид) амбалажа наменета за фармацевтски препарати. Барањата за квалитет на PVC амбалажата пропишани според Ph. Eur., DIN и DIN ISO стандардите се разликуваат во однос на предвидените параметрите за физички, за хемиски и за биолошки испитувања. Исто така, пропишани се и различни граници на дозволено отстапување на одделни параметри. Споредбата на параметрите пропишани според Ph. Eur., DIN и DIN ISO стандардите за овој вид амбалажа е направена со цел да се изврши поцелосна процена на квалитетот на PVC амбалажата. 